Research Paper

\title{
Improvement of yield of the edible and medicinal mushroom Lentinula edodes on wheat straw by use of supplemented spawn
}

\author{
Rigoberto Gaitán-Hernández, Norberto Cortés, Gerardo Mata \\ Biotechnology Resources Management Network, Institute of Ecology AC, Xalapa, Mexico.
}

Submitted: April 23, 2013; Approved: December 13, 2013.

\begin{abstract}
The research evaluated the interactions of two main factors (strain / types of spawn) on various parameters with the purpose to assess its effect on yield and biochemical composition of Lentinula edodes fruiting bodies cultivated on pasteurized wheat straw. The evaluation was made with four strains (IE-40, IE-105, IE-124 and IE-256). Different types of spawns were prepared: Control (C) (millet seed, 100\%), F1 (millet seed, $88.5 \%$; wheat bran, $8.8 \%$; peat moss, $1.3 \%$; and $\mathrm{CaSO}_{4}, 1.3 \%$ ) and F2 (the same formula as F1, but substituting the wheat bran with powdered wheat straw). Wheat straw was pasteurized by soaking it for $1 \mathrm{~h}$ in water heated to $65^{\circ} \mathrm{C}$. After this the substrate $(2 \mathrm{~kg}$ wet weight) was placed in polypropylene bags. The bags were inoculated with each spawn $(5 \% \mathrm{w} / \mathrm{w})$ and incubated in a dark room at $25^{\circ} \mathrm{C}$. A proximate analysis of mature fruiting bodies was conducted. The mean Biological Efficiency (BE) varied between 66.0\% (C-IE-256) and 320.1\% (F1-IE-124), with an average per strain of $125.6 \%$. The highest mean BE was observed on spawn F1 (188.3\%), significantly different from $\mathrm{C}$ and F2. The protein content of fruiting bodies was high, particularly in strain IE-40-F1 (17.7\%). The amount of fat varied from 1.1 (F1-IE-40) to 2.1\% (F2-IE-105) on dry matter. Carbohydrates ranged from $58.8 \%$ (F1-IE-40) to $66.1 \%$ (F1-IE-256). The energy value determined ranged from $302.9 \mathrm{kcal}$ (F1-IE-40) to $332.0 \mathrm{kcal}$ (F1-IE-256). The variability on BE observed in this study was significantly influenced by the spawn's formulation and genetic factors of the different strains.
\end{abstract}

Key words: shiitake mushroom, types of spawn, pasteurized wheat straw.

\section{Introduction}

Lentinula edodes (Berk), Pegler, better known as shiitake, has traditionally been cultivated on hardwood logs, mainly oak (Quercus spp.) in order to obtain fruiting bodies for human consumption (Kozak and Krawczyk, 1993; Sobata y Nall, 1994). However, this cultivation system represents a limiting factor and potential danger to the environment in Mexico as well as other countries due to the slow growth rate and the overuse of oak, jeopardizing the population of this important forest species. Thus, efforts to develop a more efficient, reliable and faster production system have focused on the use of enriched sawdust substrates (Przybylowicz and Donoghue, 1990).

Shiitake occupies second place in the production of cultivated fungi. Over 1,321,000 tons being produced in
China, Japan, Taiwan and Korea (Lin et al., 2000; Chang y Miles, 2004,). Currently, in addition to having a wide market for direct consumption, shiitake is known to contain important bioactive compounds that are important to the pharmacological, food and cosmetology industries (Kües and Liu, 2000).

In Mexico and other Latin American countries, experimental cultivation of shiitake has been carried out using wood shavings, e.g. Alnus, Bursera, Carpinus, Eucalyptus, Heliocarpus and Nothofagus (Mata et al., 1990; Morales and Martínez-Carrera, 1991; Morales et al., 1991; Pire et al., 2001). Coffee pulp, sugar cane bagasse, straw from several cereals and vineyard pruning have also been employed (Mata and Gaitán-Hernández, 1992, 1994; Salmones et al., 1999; Gaitán-Hernández and Mata, 2004; Gaitán-Hernández et al., 2006; Gaitán-Hernández et al., 2011). Land culti-

Send correspondence to R. Gaitán-Hernández. Biotechnology Resources Management Network, Institute of Ecology, A.C., P.O. Box 63, 91000 Xalapa, Mexico. E-mail: rigoberto.gaitan@inecol.mx. 
vated with barley and wheat crops in Mexico cover from 383,000 to 560,000 ha, generating approximately 0.7 and 2.7 million tons of straw residue, respectively (FAO, 2009). Barley and wheat are widely used in the cultivation of Agaricus bisporus (Lange) Imbach and Pleurotus spp., they also provide a great potential for the production of shiitake (Gaitán-Hernández and Mata, 2004; Gaitán-Hernández et al., 2006; Gaitán-Hernández et al., 2011).

The traditional method to cultivate shiitake mushrooms in sawdust or wood shavings involves sterilization pretreatments required to create aseptic conditions. This system on synthetic logs often requires high infrastructural costs and large energy consumption. These disadvantages, together with the scarce availability of the substrate in some regions, justify the use of alternative substrates such as wheat straw for the cultivation of $L$. edodes. Wheat straw is an abundant and relatively inexpensive raw material that successfully has been used to produce shiitake in France (Delpech and Olivier, 1991). The number of shiitake strains that are well adapted to grow on pasteurized wheat straw is relatively low (Levanon et al., 1993; Mata and Savoie, 1998; Mata et al., 2002) and this substrate is easily contaminated with antagonistic fungi. However, it has been demonstrated that the use of supplemented spawn reduces substrate contamination considerably (Mata et al., 1998; Sovoie et al., 2000).

Due to chemical and structural differences in the cultivation substrates, as well as in thermal treatments, the selection of a good spawn adapted to these conditions is critically important to ensure a high production of mushrooms in the shortest time possible. Previously millet seeds have been used as substrate to produce spawn (Mata et al., 2002), and also to increase the yield of shiitake by millet supplementation of wood chip substrate (Royse, 1996). Supplemented spawn for optimizing the cultivation of Pleurotus on coffee pulp, wheat straw and sawdust has also been assayed (Sainos et al., 2006, Mata et al., 2011; Narh et al., 2011).

The preparation of a nutritionally supplemented spawn, as well as the preadaptation of the mycelium to the final components of the culture substrate, have allowed for a considerable reduction in contamination during the first growth stages, this is an important factor for successful shiitake cultivation (Savoie et al., 2000). Since the ability of shiitake to grow on lignocellulosic substrate is related to the vigor of its mycelium, the research evaluated the interactions of two main factors (strain and types of spawn) on various parameters with the purpose to assess its effect on yield and biochemical composition of $L$. edodes fruiting bodies cultivated on pasteurized wheat straw.

\section{Materials and Methods}

\section{Strains}

Four Lentinula edodes strains evaluated in this study were as follows: L35 from Hong Kong; CS2 from Fungi Perfecti, USA; IBUG 18, donated by Ruth de Leon from Guatemala, and strain FM009 from Argentina. The strains were deposited and are maintained in the Fungi Strain Collection at the Institute of Ecology (INECOL, Xalapa, Mexico) and are registered as IE-40, IE-105, IE-124 and IE-256 respectively. Isolates were maintained on malt extract agar (MEA) (BIOXON, USA) at $25^{\circ} \mathrm{C}$.

\section{Spawn}

Different types of spawn were prepared: Control (C) (millet seed Panicum mileaceum L., 100\%) (pearl seed / Canadian origin), Formula 1 (F1) [millet seed, 88.5\%; wheat bran, 8.8\%; peat moss (Sphagnum / Canadian origin), $1.3 \% ; \mathrm{CaSO}_{4}, 1.3 \%$ ], and Formula 2 (F2) (millet seed, $88.5 \%$; powdered wheat straw, $8.8 \%$; peat moss, $1.3 \%$; $\mathrm{CaSO}_{4}, 1.3 \%$ ), percentages are based on dry matter. The final moisture content was $65 \%$. Each mixture $(300 \mathrm{~g}$ fresh wt) was placed in plastic bags and sterilized for $1.5 \mathrm{~h}$ at $121{ }^{\circ} \mathrm{C}$. The master spawn was prepared by inoculating the sterile mixture with colonized agar plugs $\left(1 \mathrm{~cm}^{2}\right)$ and incubated in complete darkness for $15 \mathrm{~d}$ at $25 \pm 1{ }^{\circ} \mathrm{C}$. Secondary spawn was prepared in new bags filled with the sterile mixture and inoculated with the first spawn (15 g master spawn). In this work we used millet seed as basal substrate because in a preliminary experiment in order to improve shiitake spawn, the authors observed greater mycelial growth and metabolic activity of several shiitake strains on pasteurized wheat straw (Mata et al., 2002).

\section{Substrate for fruiting}

Wheat straw Altiplano F2007 (Triticum aestivum L.) (harvested in the spring-summer cycle / Libres, Puebla, Mexico) was used to cultivate L. edodes. The straw was chopped into small pieces ( 3 to $5 \mathrm{~cm}$ in length) using an electric chopper and was hydrated in a container for $30 \mathrm{~min}$. Afterwards, the substrate was pasteurized by soaking it in heated water $\left(65^{\circ} \mathrm{C}\right)$ for $1 \mathrm{~h}$. The straw was then drained and the temperature reduced to $25^{\circ} \mathrm{C}$. The substrate $(2 \mathrm{~kg}$ wet wt) was placed in $32 \times 44 \mathrm{~cm}$ polypropylene bags with a micropore filter (Unicorn Import and Manufacturing, Commerce, TX). Each bag of substrate was inoculated with 5\% $(\mathrm{w} / \mathrm{w})$ of spawn and incubated in darkness at $25 \pm 1{ }^{\circ} \mathrm{C}$. After the incubation period had ended ( $45 \mathrm{~d})$ the substrate bags were transferred to a production room and the propylene bags were removed. In the production room, the relative humidity was maintained at $85-90 \%$ and the air temperature at $18 \pm 1^{\circ} \mathrm{C}$. Air recirculation was used for cooling to maintain air distribution and low $\mathrm{CO}_{2}$ levels (less than $500 \mathrm{ppm}$ ). A photoperiod of $12 \mathrm{~h}$ was provided with 350 lux illumination with lamps during the day to favor fruiting and 
obtain fruiting bodies with normal morphology and pigmentation.

Mushrooms were harvested at maturity, once the gills were exposed and the cap margin completely extended. Production data were evaluated based on biological efficiency (BE), production rate (PR) and yield (Y) (GaitánHernández et al., 2006). Mushroom size was determined according to the pileus diameter as follows: group 1 (G1) $<5 \mathrm{~cm}$, group 2 (G2) 5-9.9 cm, group 3 (G3) 10$14.9 \mathrm{~cm}$, and group $4(\mathrm{G} 4)>15 \mathrm{~cm}$.

\section{Biochemical composition of Lentinula edodes fruiting} bodies harvested.

To determine the chemical composition of mature $L$. edodes fruiting bodies harvested during the first crop, a proximate analysis was conducted: moisture (AOAC 4.1.03, method 920.39), total mineral content (AOAC 4.1.10, method 942.05), crude fat content (AOAC 4.5.01, method 920.39), protein content ( $\mathrm{N} x$ 4.38) (AOAC 4.2.08, method 934.01), using the combustion method with Leco FP-528 equipment (AOAC, 2000). Available carbohydrates were calculated from the difference. Total calories (energy value) were calculated based on dry matter according to Lau's (1982) equation: $\mathrm{kcal} / 100 \mathrm{~g}=2.62 \mathrm{x}$ (protein $\%)+4.2 \times($ carbohydrates \%) $+8.37 \times($ fat $\%)$.

\section{Statistical analysis}

A completely random design with a factorial arrangement ( 4 strains $x 3$ types of spawn) was applied to proximal analysis values, and samples were tested in triplicate. A completely random design with a factorial arrangement was also applied to production values; ten substrates bags were evaluated per treatment. An analysis of variance (ANOVA) was conducted for all values and comparison of means according to Tukey's and Duncan's test $(\mathrm{p}<0.05)$ using the statistical software Statistica (v. 7.0).

\section{Results and Discussion}

After the incubation period, substrates showed dark colored patches that eventually spread to cover the entire surface. This is consistent with its appearance cited by Przybylowicz and Donoghue (1990). The exudate indicated the maturing of the mycelium, a state that is adequate for fruiting (Donoghue and Denison, 1995).

Regarding the formula of the spawn used during the incubation period, no time difference was observed for the colonization of the substrate to take place. Table 1 shows the effect of the inoculated substrate for each spawn formula employed during the total mushroom production period (PP) for each strain evaluated. The PP differed significantly among strains $(F=28.46, \mathrm{df}=3, \mathrm{p}=0.001)$, formula $(F=120.36, \mathrm{df}=2, \mathrm{p}=0.001)$ and their interactions $(F=24.68, \mathrm{df}=6, \mathrm{p}=0.001)$. The PP varied between 34 and $56 \mathrm{~d}$ depending on the strain and spawn formulation used. However, the total weight of fresh mushrooms of two harvests was greatest for F1 $(\mathrm{p}<0.05)$. In general, the wheat straw inoculated with formula 1 and 2 produced

Table 1 - Production of fresh Lentinula edodes mushrooms on pasteurized wheat straw inoculated with three types of spawn: control (C) (millet seed), formula 1 (F1) (millet seed, wheat bran, peat moss, $\mathrm{CaSO}_{4}$ ) and formula 2 (F2) (millet seed, powdered wheat straw, peat moss, $\mathrm{CaS0}_{4}$ ).

\begin{tabular}{|c|c|c|c|c|c|}
\hline \multirow[t]{2}{*}{ Strain } & \multirow[t]{2}{*}{ Formula } & \multirow[t]{2}{*}{$\mathrm{PP}^{1,4}$} & \multirow[t]{2}{*}{ Total weight $(\mathrm{g})^{2,4}$} & \multicolumn{2}{|c|}{ Production by harvest $(\%)^{3}$} \\
\hline & & & & First & Second \\
\hline \multirow[t]{3}{*}{ IE-40 } & $\mathrm{C}$ & $40 \pm 8.0^{\mathrm{b}}$ & $473.7 \pm 197.1^{\mathrm{a}}$ & 56.1 & 43.9 \\
\hline & $\mathrm{F} 1$ & $42 \pm 6.4^{\mathrm{c}}$ & $1037.6 \pm 226.6^{\mathrm{g}}$ & 56.8 & 43.1 \\
\hline & $\mathrm{F} 2$ & $38 \pm 8.2^{\mathrm{b}}$ & $672.6 \pm 153.2^{\mathrm{d}}$ & 50.8 & 49.1 \\
\hline \multirow[t]{3}{*}{ IE-105 } & $\mathrm{C}$ & $42 \pm 7.0^{\mathrm{b}}$ & $568.2 \pm 151.5^{\mathrm{b}}$ & 54.4 & 45.5 \\
\hline & $\mathrm{F} 1$ & $49 \pm 10.9^{\mathrm{e}}$ & $833.5 \pm 125.4^{\mathrm{f}}$ & 63.8 & 36.1 \\
\hline & $\mathrm{F} 2$ & $43 \pm 6.8^{\mathrm{d}}$ & $735.5 \pm 131.2^{\mathrm{d}}$ & 60.7 & 39.3 \\
\hline \multirow[t]{3}{*}{ IE-124 } & $\mathrm{C}$ & $34 \pm 6.9^{\mathrm{a}}$ & $453.9 \pm 191.1^{\mathrm{a}}$ & 50.5 & 49.4 \\
\hline & $\mathrm{F} 1$ & $46 \pm 8.4^{\mathrm{d}}$ & $1952.9 \pm 271.8^{\mathrm{h}}$ & 50.5 & 49.4 \\
\hline & $\mathrm{F} 2$ & $56 \pm 2.3^{\mathrm{f}}$ & $717.6 \pm 186.6^{\mathrm{d}}$ & 52.8 & 47.1 \\
\hline \multirow[t]{3}{*}{ IE-256 } & $\mathrm{C}$ & $46 \pm 5.1^{\mathrm{d}}$ & $402.7 \pm 94.1^{\mathrm{a}}$ & 61.0 & 38.9 \\
\hline & F1 & $41 \pm 7.4^{\mathrm{c}}$ & $771.8 \pm 123.7^{\mathrm{e}}$ & 61.9 & 38.0 \\
\hline & $\mathrm{F} 2$ & $49 \pm 9.4^{\mathrm{e}}$ & $576.9 \pm 208.1^{\mathrm{c}}$ & 72.0 & 27.9 \\
\hline
\end{tabular}

${ }^{1}$ Production Period (time from primordia formation to last harvest).

${ }^{2}$ Fresh weight of mushrooms harvested from ten replicates.

${ }^{3}$ Distribution of total weight mushrooms obtained in each harvest, estimated in percentage.

${ }^{4}$ Means \pm standard deviation followed by different letters indicates significant differences according to Duncan $(\mathrm{p}<0.05)$. 
greater yields than that inoculated with the control (C). The longest periods of production were observed for substrates inoculated with F1 (IE-40, 42 d), F1 (IE-105, 49 d), F2 (IE-124, 56 d) and F2 (IE-256, 49 d) (Table 1). Mushroom yields were significantly affected by strain $(F=28.46$, $\mathrm{df}=3, \mathrm{p}=0.001)$, formula $(F=120.36, \mathrm{df}=2, \mathrm{p}=0.001)$ and their interactions $(F=24.68, \mathrm{df}=6, \mathrm{p}=0.001)$. The total production of fresh mushrooms produced varied between 437.7 (C-IE-40) to $1952.9 \mathrm{~g}$ (F1-IE-124) ( $\mathrm{p}<0.05)$. The number of harvests obtained for all the strains from the inoculated substrate using each formula was two. In general, $50 \%$ to $72 \%$ of the total production was obtained during the first harvest. The highest production percentage observed for the first harvest was that of the substrate inoculated with the supplemented spawn (Table 1).

Mushroom yields per size group during the first and second harvest were significantly affected by strain and formula (Table 2). Mushrooms produced from the substrate inoculated with control (C) spawn were mainly of three sizes, with the exception of the IE-124 strain that also produced a size G4. Mushrooms of G2 and G3 sizes were predominant in the first and second harvests. The greatest presence of $\mathrm{G} 2$ in the substrate inoculated with $\mathrm{C}$ was for strain IE-105 (60.3\%) and strain IE-256 (53.1\%) for the first harvest, whilst these same strains produced mainly G3 mushrooms in the second harvest: $64.7 \%$ and $62.3 \%$, respectively. Substrate inoculated with C (all strains) aver-

Table 2 - P-values from analysis of variance (ANOVA) for mushroom size of Lentinula edodes harvested from pasteurized wheat straw inoculated with the control, formula 1 and formula 2.

\begin{tabular}{lccc}
\hline & \multicolumn{3}{c}{ First harvest } \\
\cline { 2 - 4 } Effect & DF & F & $\mathrm{p}^{*}$ \\
\hline Strain & 3 & 4.27 & 0.0056 \\
Formula & 2 & 28.99 & 0.0001 \\
Size & 3 & 68.99 & 0.0001 \\
Strain x Formula & 6 & 5.56 & 0.0001 \\
Strain x Size & 9 & 23.69 & 0.0001 \\
Formula x Size & 6 & 4.91 & 0.0001 \\
Strain x Formula x Size & 18 & 4.12 & 0.0001 \\
& & Second harvest \\
Strain & 3 & 25.71 & 0.0001 \\
Formula & 2 & 31.72 & 0.0001 \\
Size & 3 & 81.40 & 0.0001 \\
Strain x Formula & 6 & 11.68 & 0.0001 \\
Strain x Size & 9 & 14.09 & 0.0001 \\
Formula x Size & 6 & 7.91 & 0.0001 \\
Strain x Formula x Size & 18 & 7.83 & 0.0001 \\
\hline
\end{tabular}

${ }^{*}$ p values $<0.05$ were considered significant. aged $84 \%$ of the total production for $\mathrm{G} 2$ and $\mathrm{G} 3$ during the first and second harvesting cycles. Substrate inoculated with $\mathrm{F} 1$ yielded mushrooms in all four groups, with the exception of IE-105 which did not produce G4 mushrooms during the first harvest and IE-256 which did not produce G4 mushrooms in the first or second harvest. Strain IE-124 did not produce mushrooms of G1 size in either harvest but developed abundant mushrooms of the remaining groups. The predominant production corresponded to G2 and G3 mushrooms in the first harvest and G3 and G4 in the second $(\mathrm{p}<0.05)$. The greatest presence of G2 mushrooms in the substrate inoculated with F1 in the first harvest was for IE-105 (60.8\%) and IE-256 (59.0\%) $(\mathrm{p}<0.05)$. These same strains produced mainly G3 mushrooms in the second harvest: $49.59 \%$ and $49.88 \%$, respectively. The IE- 124 strain stands out in both harvests where it generated more than $55 \%$ G4 mushrooms (>15 cm). The substrate inoculated with $\mathrm{F} 1$ yielded $66 \%$ of $\mathrm{G} 2$ and G3 mushrooms in the first harvest and more than $68 \% \mathrm{G} 3$ and G4 in the second.

Substrate inoculated with F2 produced mushrooms mainly of three sizes in the first harvest, with the exception of the IE-124 strain which produced G4 mushrooms, whilst in the case of the second harvest, all strains developed mushrooms of four sizes with the exception of IE-256 strain which did not produce G4 mushrooms. IE-105 did not produce $\mathrm{G} 1$ mushrooms but the best represented groups sizes were from $\mathrm{G} 2$ to $\mathrm{G} 4$. The predominant production of all strains corresponded to G2 and G3 for both harvests. A greater presence of $\mathrm{G} 2$ mushrooms for the first harvest was observed for IE-105 (56.6\%) and IE-256 (45.4\%), but $52.2 \%$ of G4 mushrooms was also recorded for IE-40. For IE-105, $40.6 \%$ of G4 mushrooms were produced in the second harvest while IE- 256 produced $44.1 \%$ of the G3 category. IE-124 strain stands out as producing mushrooms of G4 size in both harvests, $34.4 \%$ in the first and $28.8 \%$ in the second. In general, the groups with the greatest representation were $\mathrm{G} 2$ and $\mathrm{G} 3$ with the larger size corresponding to the substrate inoculated with $\mathrm{F} 1$ and $\mathrm{F} 2$, F1 producing more G4 mushrooms.

The BE was significantly affected by strain $(F=28.46, \mathrm{df}=3, \mathrm{p}=0.001)$, formula $(F=120.36, \mathrm{df}=2$, $\mathrm{p}=0.001)$ and their interactions $(F=24.68, \mathrm{df}=6$, $\mathrm{p}=0.001)$. The average $\mathrm{BE}$ for pasteurized wheat straw ranged between $66.0 \%$ (C-IE-256) and 320.1\% (F1-IE124) showing an average per formula of $77.8 \%$ (C), $188.3 \%$ (F1) and $110.7 \%$ (F2) with a statistical difference between the three types of spawns $(\mathrm{p}<0.05)$. The lowest BE per strain was recorded for IE-256 (95.7\%) and the highest for IE-124 (170.7\%). BE means were statistically different at $p$ $<0.05$ among all four strains. Each strain manifested its highest BE when the substrate was inoculated with F1 and F2 (Table 3).

The PR was significantly affected by strain $(F=22.16, \mathrm{df}=3, \mathrm{p}=0.001)$, formula $(F=100.59, \mathrm{df}=2$, $\mathrm{p}=0.001)$ and their interactions $(F=21.59$, df $=6$, 
Table 3 - Biological efficiency (\%) of Lentinula edodes strains on pasteurized wheat straw inoculated with three types of spawn.

\begin{tabular}{lccccc}
\hline \multicolumn{5}{c}{ Strain } \\
\hline Formula & IE-40 & IE-105 & IE-124 & IE-256 & Means \\
\hline C & $77.6 \pm 32.3^{\mathrm{c}}$ & $93.1 \pm 24.8^{\mathrm{d}}$ & $74.4 \pm 31.33^{\mathrm{b}}$ & $66.0 \pm 15.4^{\mathrm{a}}$ & $77.8^{\mathrm{a}}$ \\
F1 & $170.1 \pm 37.1^{\mathrm{h}}$ & $136.6 \pm 20.5^{\mathrm{g}}$ & $320.1 \pm 44.5^{\mathrm{i}}$ & $126.5 \pm 20.2^{\mathrm{f}}$ & $188.3^{\mathrm{c}}$ \\
F2 & $110.2 \pm 25.1^{\mathrm{d}}$ & $120.5 \pm 21.5^{\mathrm{e}}$ & $117.6 \pm 30.5^{\mathrm{e}}$ & $94.5 \pm 34.1^{\mathrm{d}}$ & $110.7^{\mathrm{b}}$ \\
Means & $119.3^{\mathrm{b}}$ & $116.7^{\mathrm{ab}}$ & $170.7^{\mathrm{c}}$ & $95.7^{\mathrm{a}}$ & \\
\hline
\end{tabular}

Values are mean \pm standard deviation. Means that do not have at least one letter in common of each strain in three formulae and only among means are significantly different (Tukey $\mathrm{p}<0.05$ ).

$\mathrm{p}=0.001)$. The average PR ranged between $0.3 \%(\mathrm{C}$-IE40 ) and 3.4\% (F1-IE-124), showing an average per formula of $0.8 \%(\mathrm{C}), 2.07 \%$ (F1) and 1.1\% (F2) (Table 4). Differences were statistically significant $(p<0.05)$. The strain which presented the lowest PR was IE-256 (1.0\%) with no statistical difference with the IE-105 strain $(\mathrm{p}>0.05)$ and the highest the IE-124 (1.8\%), statistically different from all the other strains $(p<0.05)$. The PR values followed a similar trend to the BE where the highest PR value was evident in the case of the substrate inoculated with F1 and F2 (Table 4).

Previous studies report shiitake cultivation on wheat straw. Mata et al. (1998) used wheat straw pasteurized at $65{ }^{\circ} \mathrm{C}$ and supplemented. In that study, BE was $38 \%$ and 44\%. However, Savoie et al. (2000) obtained a BE of approximately $60 \%$ using pasteurized wheat straw and Gaitán-Hernández and Mata (2004) reported a BE of 46.9\% and $50 \%$ when they used two strains of shiitake on wheat straw, in this case pasteurizing through hot water immersion. Gaitán-Hernández et al. (2006) used sterilized wheat and barley straw in the cultivation of four shiitake strains. In that study, BE of $49 \%$ in wheat straw and $77 \%$ in barley straw were obtained. In the present higher BE were reached utilizing pasteurized substrate and supplemented spawn. The BE values reported in previous studies vary according to the strain, substrate, supplements and treatments used (Mata and Gaitán-Hernández, 1994; Salmones et al., 1999; Leifa et al., 2000; Morais et al., 2000; Pire et al., 2001; Philippoussis et al., 2003, 2007; Rossi et al., 2003; Fung et al., 2005). Nevertheless, very few studies have been carried out to improve the spawn and prove its effect in the growth and production of shiitake (Royse, 1996; Mata et al., 2002).

The average PR reported in our study are higher than those cited by Gaitán-Hernández et al. (2006) in shiitake cultivated on barley straw and sterile wheat straw: 1.1\% and $0.6 \%$, respectively. On the other hand Royse (1985) reported PRs of $0.2 \%$ and $0.7 \%$ when shiitake was grown on enriched sterile sawdust.

Delpech and Oliver (1991) evaluated shiitake yields grown on supplemented and steam pasteurized $\left(60{ }^{\circ} \mathrm{C}\right.$ for $24 \mathrm{~h}$ ) wheat straw. Yields values were between $11.9 \%$ and $15.9 \%$, far lower than those obtained in the present study, where average yields (Y) per each formula were $23.7 \%$ for C, $57.4 \%$ for F1 and $33.7 \%$ for F2 (Table 5) and where the highest value for the substrate inoculated with F1 of the IE-124 strain was $97.6 \%$. The $\mathrm{Y}$ was significantly affected by strain $(F=28.46, \mathrm{df}=3, \mathrm{p}=0.001)$, formula $(F=120.36, \mathrm{df}=2, \mathrm{p}=0.001)$ and their interactions $(F=24.68, \mathrm{df}=6, \mathrm{p}=0.001)$. These yields are also higher than those reached by Kilpatrick et al. (2000) using sterile wheat straw (5\% to $31 \%$ ) supplemented with wheat bran and millet. In general, based on BE, PR, and Y values and the size of the mushrooms produced, the best spawn formulation was F1 and IE-124 was the most productive strain.

In the present work higher $\mathrm{BE}, \mathrm{PR}$ and $\mathrm{Y}$ were reached utilizing pasteurized substrate and supplemented spawn. The reason for this remains unknown, but may be related to the supplementation with nutrient added at each

Table 4 - Production rate (\%) of Lentinula edodes strains on pasteurized wheat straw inoculated with three types of spawn.

\begin{tabular}{|c|c|c|c|c|c|}
\hline \multicolumn{6}{|c|}{ Strain } \\
\hline Formula & IE-40 & IE-105 & IE-124 & IE-256 & Means \\
\hline $\mathrm{C}$ & $0.3 \pm 0.4^{\mathrm{b}}$ & $1.0 \pm 0.2^{\mathrm{c}}$ & $0.9 \pm 0.3^{b}$ & $0.6 \pm 0.17^{\mathrm{a}}$ & $0.8^{\mathrm{a}}$ \\
\hline F1 & $1.9 \pm 0.4^{\mathrm{f}}$ & $1.3 \pm 0.3^{\mathrm{e}}$ & $3.4 \pm 0.5^{\mathrm{h}}$ & $1.49 \pm 0.2^{\mathrm{f}}$ & $2.0^{\mathrm{c}}$ \\
\hline $\mathrm{F} 2$ & $1.2 \pm 0.2^{\mathrm{c}}$ & $1.3 \pm 0.2^{\mathrm{d}}$ & $1.1 \pm 0.2^{\mathrm{c}}$ & $0.9 \pm 0.3^{\mathrm{c}}$ & $1.1^{\mathrm{b}}$ \\
\hline Means & $1.3^{\mathrm{b}}$ & $1.2^{\mathrm{ab}}$ & $1.8^{\mathrm{c}}$ & $1.0^{\mathrm{a}}$ & \\
\hline
\end{tabular}

Values are mean and \pm are standard deviations. Means that do not have at least one letter in common of each strain in three formulae and only among means are significantly different (Tukey $\mathrm{p}<0.05$ ). 
Table 5 - Yield (\%) ${ }^{1}$ of Lentinula edodes strains on pasteurized wheat straw inoculated with three types of spawn.

\begin{tabular}{lccccc}
\hline \multicolumn{5}{c}{ Strain } & \\
\hline Formula & IE-40 & IE-105 & IE-124 & IE-256 & Means \\
C & $23.6 \pm 9.8^{\mathrm{c}}$ & $28.4 \pm 7.5^{\mathrm{d}}$ & $22.6 \pm 9.5^{\mathrm{b}}$ & $20.1 \pm 4.7^{\mathrm{a}}$ & $23.7^{\mathrm{a}}$ \\
F1 & $51.8 \pm 11.3^{\mathrm{h}}$ & $41.6 \pm 6.2^{\mathrm{g}}$ & $97.6 \pm 13.5^{\mathrm{i}}$ & $38.5 \pm 6.1^{\mathrm{f}}$ & $57.4^{\mathrm{c}}$ \\
F2 & $33.6 \pm 7.6^{\mathrm{d}}$ & $36.7 \pm 6.5^{\mathrm{e}}$ & $35.8 \pm 9.3^{\mathrm{e}}$ & $28.8 \pm 10.4^{\mathrm{d}}$ & $33.7^{\mathrm{b}}$ \\
Means & $36.3^{\mathrm{b}}$ & $35.6^{\mathrm{ab}}$ & $52.0^{\mathrm{c}}$ & $29.1^{\mathrm{a}}$ & \\
\hline
\end{tabular}

spawn type (wheat bran, powdered wheat straw). On the other hand, the strain's capacity to invade this substrate is related to the shiitake's strain adaptation to the particular system.

Mature fruiting bodies produced on the substrate inoculated with each spawn formulation show a normal development and morphology. The proximate composition of the fruiting bodies of Lentinula edodes was significantly affected by strain and formula (Table 6, 7). The protein content was high, particularly in the case of F1-IE-40 and F1-IE-105 showing a positive correlation in its biological efficiency $\left(r^{2}=0.74\right)$. These results coincide with those registered by Salmones et al. (1999) and Morais et al.
(2000) for fruiting bodies obtained from different sterile substrates, as well as those cited by Philippoussus et al. (2007) for mushrooms harvested from sterile supplemented wheat straw (18\% d.w). The ash and raw fat contents were also similar to those reported by Morais et al. (2000) for mushrooms cultivated on sterile wood shavings. A variation in the ash content was observed according to the spawn formulation. However, there were no statistical differences $(\mathrm{p}>0.05)$ for $\mathrm{C}$ and $\mathrm{F} 1$ for IE-105 or IE-256 strain.

The fat content ranged from 1.1 (F1-IE-40) to $2.1 \%$ (F2-IE-105) of dry matter and differed among the formulae $(\mathrm{p}<0.05)$. Carbohydrates varied from $58.8 \%$ (F1-IE-40) to $66.1 \%$ (F1-IE-256) and were higher than those cited for

Table 6 - Analysis of variance (ANOVA) for the proximate composition of the fruiting bodies of Lentinula edodes harvested from pasteurized wheat straw inoculated with different types of spawns.

\begin{tabular}{|c|c|c|c|c|}
\hline Factor & Effect & DF & $\mathrm{F}$ & $\mathrm{p}^{*}$ \\
\hline & Strain & 3 & 3.20 & 0.0412 \\
\hline \multirow[t]{3}{*}{ Moisture } & Formula & 2 & 9.13 & 0.0011 \\
\hline & Strain-Formula & 3 & 8.89 & 0.0001 \\
\hline & Strain & 3 & 77.10 & 0.0001 \\
\hline \multirow[t]{3}{*}{ Ash } & Formula & 2 & 58.27 & 0.0001 \\
\hline & Strain-Formula & 6 & 94.62 & 0.0001 \\
\hline & Strain & 3 & 42.97 & 0.0001 \\
\hline \multirow[t]{3}{*}{ Crude fat } & Formula & 2 & 41.14 & 0.0001 \\
\hline & Strain-Formula & 6 & 19.07 & 0.0001 \\
\hline & Strain & 3 & 32059 & 0.0001 \\
\hline \multirow[t]{3}{*}{ Crude protein } & Formula & 2 & 59857 & 0.0001 \\
\hline & Strain-Formula & 6 & 68701 & 0.0001 \\
\hline & Strain & 3 & 18.0 & 0.0001 \\
\hline \multirow[t]{3}{*}{ Carbohydrates } & Formula & 2 & 23.9 & 0.0001 \\
\hline & Strain-Formula & 6 & 43.5 & 0.0001 \\
\hline & Strain & 3 & 18.2 & 0.0001 \\
\hline \multirow[t]{2}{*}{ Energy value } & Formula & 2 & 6.4 & 0.0057 \\
\hline & Strain-Formula & 6 & 26.9 & 0.0001 \\
\hline
\end{tabular}

${ }^{*}$ p values $<0.05$ were considered significant. 
Table 7 - Chemical composition of Lentinula edodes fruiting bodies harvested from pasteurized wheat straw inoculated with three types of spawn (see Table 1).

\begin{tabular}{|c|c|c|c|c|c|c|c|}
\hline Strain & $\mathrm{F}^{1}$ & $\mathrm{M}^{2}$ & $A^{3}$ & $\mathrm{CF}^{4}$ & $\mathrm{CP}^{5}$ & $\mathrm{CH}^{6}$ & $\mathrm{EV}^{7}$ \\
\hline \multirow{3}{*}{ IE-40 } & $\mathrm{C}$ & $85.7 \pm 0.5^{\mathrm{a}}$ & $4.1 \pm 0.1^{\mathrm{f}}$ & $1.5 \pm 0.1^{\mathrm{e}}$ & $14.4 \pm 0.0^{\mathrm{a}}$ & $65.6 \pm 0.8^{g}$ & $326.2 \pm 2.5^{\mathrm{f}}$ \\
\hline & $\mathrm{F} 1$ & $82.3 \pm 1.0^{\mathrm{e}}$ & $4.6 \pm 0.0^{\mathrm{i}}$ & $1.1 \pm 0.0^{\mathrm{a}}$ & $17.7 \pm 0.0^{\mathrm{k}}$ & $58.8 \pm 1.0^{\mathrm{a}}$ & $302.9 \pm 4.6^{\mathrm{a}}$ \\
\hline & F2 & $84.0 \pm 0.2^{\mathrm{c}}$ & $3.8 \pm 0.0^{\mathrm{b}}$ & $1.4 \pm 0.1^{\mathrm{c}}$ & $15.9 \pm 0.0^{\mathrm{h}}$ & $62.9 \pm 0.2^{\mathrm{d}}$ & $317.3 \pm 1.5^{\mathrm{d}}$ \\
\hline \multirow{3}{*}{ IE-105 } & $\mathrm{C}$ & $84.8 \pm 0.5^{\mathrm{b}}$ & $3.8 \pm 0.1^{\mathrm{c}}$ & $1.1 \pm 0.0^{\mathrm{a}}$ & $15.4 \pm 0.0^{\mathrm{g}}$ & $64.2 \pm 0.5^{\mathrm{f}}$ & $320.2 \pm 2.1^{\mathrm{e}}$ \\
\hline & $\mathrm{F} 1$ & $82.5 \pm 0.7^{\mathrm{e}}$ & $4.0 \pm 0.1^{\mathrm{d}}$ & $1.4 \pm 0.0^{\mathrm{c}}$ & $17.4 \pm 0.0^{\mathrm{j}}$ & $59.7 \pm 0.8^{\mathrm{b}}$ & $308.6 \pm 3.9^{b}$ \\
\hline & F2 & $84.8 \pm 1.0^{\mathrm{b}}$ & $3.8 \pm 0.1^{\mathrm{c}}$ & $2.1 \pm 0.1^{\mathrm{h}}$ & $15.1 \pm 0.0^{\mathrm{e}}$ & $63.6 \pm 0.9^{\mathrm{e}}$ & $325.0 \pm 4.3^{\mathrm{f}}$ \\
\hline \multirow{3}{*}{ IE-124 } & $\mathrm{C}$ & $84.7 \pm 0.6^{\mathrm{b}}$ & $4.4 \pm 0.1^{\mathrm{h}}$ & $1.2 \pm 0.0^{\mathrm{c}}$ & $15.2 \pm 0.0^{\mathrm{f}}$ & $63.8 \pm 0.7^{\mathrm{e}}$ & $318.3 \pm 2.7^{\mathrm{e}}$ \\
\hline & $\mathrm{F} 1$ & $85.2 \pm 0.9^{\mathrm{b}}$ & $3.8 \pm 0.0^{\mathrm{b}}$ & $1.2 \pm 0.0^{\mathrm{b}}$ & $14.7 \pm 0.0^{\mathrm{b}}$ & $65.4 \pm 0.6^{\mathrm{g}}$ & $323.8 \pm 2.8^{\mathrm{f}}$ \\
\hline & F2 & $83.3 \pm 0.6^{\mathrm{d}}$ & $4.2 \pm 0.0^{\mathrm{g}}$ & $1.3 \pm 0.1^{\mathrm{c}}$ & $16.6 \pm 0.0^{\mathrm{i}}$ & $61.0 \pm 0.5^{\mathrm{c}}$ & $311.5 \pm 3.2^{\mathrm{c}}$ \\
\hline \multirow{3}{*}{ IE-256 } & $\mathrm{C}$ & $84.7 \pm 0.4^{b}$ & $4.1 \pm 0.2^{\mathrm{e}}$ & $1.5 \pm 0.0^{\mathrm{d}}$ & $15.2 \pm 0.0^{\mathrm{f}}$ & $63.7 \pm 0.4^{\mathrm{e}}$ & $320.6 \pm 2.4^{\mathrm{e}}$ \\
\hline & F1 & $85.1 \pm 0.3^{b}$ & $2.2 \pm 0.0^{\mathrm{a}}$ & $1.8 \pm 0.2^{\mathrm{f}}$ & $14.8 \pm 0.0^{\mathrm{c}}$ & $66.1 \pm 0.1^{\mathrm{h}}$ & $332.0 \pm 2.0^{\mathrm{g}}$ \\
\hline & $\mathrm{F} 2$ & $84.9 \pm 0.8^{\mathrm{b}}$ & $4.1 \pm 0.1^{\mathrm{e}}$ & $2.0 \pm 0.0^{\mathrm{g}}$ & $15.0 \pm 0.0^{\mathrm{d}}$ & $63.7 \pm 0.6^{\mathrm{e}}$ & $324.3 \pm 3.0^{\mathrm{f}}$ \\
\hline
\end{tabular}

${ }^{1} \mathrm{~F}$ formula; ${ }^{2} \mathrm{M}$ moisture; ${ }^{3} \mathrm{~A}$ ash; ${ }^{4} \mathrm{CF}$ crude fat; ${ }^{5} \mathrm{CP}$ crude protein $[\mathrm{Nx} 4.38(\mathrm{kcal})] ;{ }^{6} \mathrm{CH}$ carbohydrates; ${ }^{7} \mathrm{EV}$ energy value $[\mathrm{kcal} / 100 \mathrm{~g}=2.62 \mathrm{x}(\%$ of protein $)+4.2 \times(\%$ of carbohydrates $)+8.37 \times(\%$ of fat $)]$. Values are means \pm standard deviation of three replicates. Means in a column with different superscripts are significantly different (Tukey $\mathrm{p}<0.05$ ). All values are on a dry matter basis, except moisture (percentage of fresh mushroom wt).

Agaricus sp. (59.9\%) but lower than those cited for Pleurotus spp. (74\%) (Mendívil-Salmón et al., 2001). Carbohydrate contents were also lower than those obtained by Gaitán-Hernández et al. (2006) for shiitake produced on sterile wheat straw (75.8-79.2\%). The energy values of the mushrooms reported in this study ranged from $302.9 \mathrm{kcal}$ (F1-IE-40) to $332.0 \mathrm{kcal}$ (F1-IE-256) and were lower than those cited by Gaitán-Hernández et al. (2006) for shiitake mushrooms grown on sterile wheat straw (377.4$388.0 \mathrm{kcal})$.

The selection of a good spawn adapted to these conditions is critically important to ensure a high production of bodies in the shortest time possible. The bioconversion process of pasteurized wheat straw using a nutritionally supplemented spawn offers the possibility to increase yield and generate an alternative food product containing high percentages of total carbohydrates and proteins with an equivalent or higher nutritional value when compared to other food products.

The research clearly demonstrates the need for well specified strain and spawn combinations for any production and that any farmer needs to carefully evaluate any change to his production practices.

\section{Acknowledgments}

The authors wish to express their gratitude to the Ecology Institute (INECOL) and to the National Council of Science and Technology (CONACyT) of Mexico for their financial support. Thanks are also given to Alma Edith Rodriguez Estrada Ph. D. for her help in the English corrections of this paper.

\section{References}

AOAC (2000) Official Methods of Analysis of the Association of Official Analytical Chemist. 17th ed. AOAC, Arlington.

Chang ST, Miles, PG (2004) Mushrooms: Cultivation, Nutritional Value, Medicinal Effect, and Environmental Impact. CRC Press, Boca Ratón.

Delpech P, Olivier JM (1991) Cultivation of shiitake on straw based pasteurized substrates. In: Maher, J. (ed) Science and Cultivation of Edible Fungi. Balkema, Rotterdam, pp 523528.

Donoghue JD, Denison WC (1995) Shiitake cultivation: Gas phase during incubation influences productivity. Mycologia 87:239-244.

FAO (2009) Organización de las Naciones Unidas para la Agricultura y la Alimentación. Available at: http://www.fao.org/index_es.htm. Accessed 25 November 2012.

Fung YW, Fung TW, Franco M (2005) Evaluation of different Colombian agroindustrial wastes as substrates for the growth production of Lentinula edodes. Berk. Pegler (Shiitake). In: Tan, Q., Zhang, J., Chen, M., Cao, H., Buswell, J.A. (eds) The Fifth International Conference on Mushroom Biology and Mushroom Products. Shanghai, pp 285-290.

Gaitán-Hernández R, Mata G (2004) Cultivation of edible mushroom Lentinula edodes (shiitake) in pasteurized wheat straw. Alternative use of geothermal energy in Mexico. Eng Life Sci 4:363-367.

Gaitán-Hernández R, Esqueda M, Gutiérrez A, Sánchez A, Beltrán-García M, Mata G (2006) Bioconversion of agrowastes by Lentinula edodes: The high potential of viticulture residues. Appl Microbiol Biot 71:432-439.

Gaitán-Hernández R, Esqueda M, Gutiérrez A, Beltrán-García M. (2011) Quantitative changes in the biochemical composition 
of lignocellulosic residues during the vegetative growth of Lentinula edodes. Braz J Microbiol 42:30-40.

Kilpatrick M, Murray DJ, Ward F (2000) Influence of substrate formulation and autoclave treatment on Lentinula edodes production. In: Van Griensven (ed) Science and Cultivation of Edible Fungi. Balkema Publishers, Rotterdam, pp 803810

Kozak ME, Krawczyk J (1993) Growing shiitake mushroom in a continental climate. Marinette, Wisconsin.

Kües U, Liu Y (2000) Fruiting body production in Basidiomicetes. Appl Microbiol Biot 54:141-152.

Lau OW (1982) Methods of chemical analysis of mushrooms. In: Chang, S.T., Quimio, T.H. (eds) Tropical Mushrooms: Biological Nature and Cultivation Methods. The Chinese Univ. Press, Hong Kong, pp 87-115.

Leifa F, Pandey A, Soccol CR (2000) Solid state cultivation-an efficient method to use toxic agro-industrial residues. J Basic Microb 40:187-197.

Levanon D, Rothschild N, Danai O, Masaphy S (1993) Strain selection for cultivation of shiitake mushrooms (Lentinus edodes) on straw. Bioresource Technol 45:9-12.

Lin FC, Yang XM, Wang ZW (2000) Cultivation of the black oak mushroom Lentinula edodes in China. Mush Sci 15:955958.

Mata G, Gaitán-Hernández R (1992) Utilización de pulpa de café mezclada con viruta de madera para el crecimiento micelial de Lentinus boryanus y Lentinus edodes. Rev Mex Mic 8:125-129.

Mata G, Gaitán-Hernández R (1994) Avances en el cultivo del shiitake en pulpa de café. Rev Iberoam Micol 11:90-91.

Mata G, Ortega Sánchez C, Pérez Merlo R (2011) Inóculo suplementado: Evaluación de un método para optimizar la producción de inóculo para el cultivo de Pleurotus en pulpa de café. Rev Mex Mic 34:53-61.

Mata G, Savoie JM (1998) Extracellular enzyme activity in six Lentinula edodes strains during cultivation in wheat straw. World J Microb Biot 14:513-519.

Mata G, Salmones D, Guzmán G (1990) Cultivo del shiitake japonés, Lentinus edodes, en bolsas con viruta de madera. Rev Mex Mic 6:245-251.

Mata G, Savoie JM, Delpech P, Olivier JM (1998) Reduction in the incidence of Trichoderma spp. using substrate suplementation with peat and an alternative spawn during cultivation of Lentinula edodes on pasteurized wheat straw. Agronomie 18:515-520.

Mata G, Gaitán-Hernández R, Pérez-Merlo R, Ortega C (2002) Improvement of shiitake spawn for culturing on pasteurized wheat straw. In: Sánchez, J.E., Huerta, G., Montiel, E. (eds) Mushroom Biology and Mushroom Products. UAEM, México, pp 303-309.

Narh DL, Obodai M, Baka D, Dzomeku M (2011). The efficacy of sorghum and millet grains in spawn production of Pleurotus ostreatus (Jacq. Ex. Fr.) Kummer. Int Food Res J 18:11431148 .
Mendívil-Salmón C, Sánchez A, Grijalva I, Esqueda M (2001) Composición química de Pleurotus cultivado sobre residuos vitivinícolas. Rev Iber Tecnología Postcosecha 3:207-214.

Morais MH, Ramos AC, Matos N, Olivera EJS (2000) Note. Production of shiitake mushroom (Lentinus edodes) on lignocellulosic residues. Food Sci Technol Int 6:123-128.

Morales P, Martínez-Carrera D (1991) Bursera sawdust as a substrate for shiitake cultivation. Micol Neotrop Apl 4:41-47.

Morales P, Martínez-Carrera D, Martínez-Sánchez W (1991) Cultivo de shiitake sobre diversos substratos en México. Micol Neotrop Apl 4:75-81.

Philippoussis AN, Diamantopoulou PA, Zervakis GL (2003) Correlation of the properties of several lignocellulosic substrates to the crop performance of the shiitake mushroom Lentinula edodes. World J Microb Biot 19:551-557.

Philippoussis AN, Diamantopoulou PA, Israilides C (2007) Productivity of agricultural residues used for the cultivation of the medicinal fungus Lentinula edodes. Int Biodeter Biodegr 59:216-219

Pire DG, Wright JE, Albertó E (2001) Cultivation on shiitake using sawdust from widely available local woods in Argentine. Micol Apl Int 13:87-91.

Przybylowicz P, Donoghue J (1990) Shiitake growers handbook. The art and science of mushroom cultivation. Kendall/Hunt Publishing Company, Dubuque.

Rossi IH, Monteiro AC, Machado JO, Andrioli JL, Barbosa JC (2003) Shiiatke Lentinula edodes production on a sterilized bagasse substrate enriched with rice bran and sugarcane molasses. Braz J Microbiol 34:66-71.

Royse DJ (1985). Effect of spawn run time and substrate nutrition on yield and size of the shiitake mushroom. Mycologia 77:756-762.

Royse DJ (1996) Yield stimulation of shiitake by millet supplementation of wood chip substrate. In: Royse, D.J. (ed) Mushroom Biology and Mushroom Products. Penn State Univ. Press, Pennsylvania, pp 277-283.

Sainos E, Díaz-Godínez G, Loera O, Montiel-González AM, Sánchez C (2006) Growth of Pleurotus ostreatus on wheat straw and wheat-grain-based media: Biochemical aspects and preparation of mushroom inoculum. Appl Microbiol Biotechnol 72:812-815.

Salmones D, Mata G, Ramos LM, Waliszeski KN (1999) Cultivation of shiitake mushroom, Lentinula edodes, in several lignocellulosic materials originating from the subtropics. Agronomie 19:13-19.

Savoie JM, Delpech P, Billete C, Mata G (2000) Inoculum adaptation changes the outcome of competition between Lentinula edodes and Trichoderma spp. during shiitake cultivation on pasteurized wheat straw. Mush Sci 15:667-674.

Sobata C, Nall H (1994) Shiitake Mushroom Production on Logs. Alabama Cooperative Extension Program, Alabama.

All the content of the journal, except where otherwise noted, is licensed under a Creative Commons License CC BY-NC. 